\title{
Post Disaster Students' Mental Spirituality Development at Government Junior High Schools in Palu
}

\author{
Muhammad Abdul Razak ${ }^{1 *}$ Saefuddin Saefuddin ${ }^{2}$, and Ruslin Ruslin ${ }^{3}$ \\ 1 Islamic Education Department, Postgraduate, Institut Agama Islam Negeri Palu \\ 2 Islamic Education Department, Postgraduate, Institut Agama Islam Negeri Palu \\ ${ }^{3}$ Islamic Education Department, Postgraduate, Institut Agama Islam Negeri Palu
}

ABSTRACT

This study discusses teachers strategy to improve students mental sorituality after natural disasters at a junir high school in Palu city. This study was conducted to help students to recover their mental spirituality after experienced traumatic natural disasters. In conducting the study, we used a qualitative case study method. The case of this study was a stateb junior high school in Palu city. Data were gathered through direct field observation, indepth interviews which involve teachers and the school principle. We also analyzed written material, such as the school teaching activities, to understand how the teachers at the school helped students to recover their mental spirituality during post disasters period. Our study found that teachers has been able to carry out mental and spiritual recovery of the students after the natural disaster in Palu. The students who were initially lazy to participate in religious activities became diligent. Then the students who initially rarely prayed became diligent to pray. The teachers awaken students' awareness of the importance of maintaining spirituality after experiencing a disaster through various religious activities in the school environment
ARTICLE

INFORMATION

Keywords:

Post disaster, sprituality, mental, mental recovery 


\section{Introduction}

In recent years, natural disasters have always occurred and this has disrupted the economy and the peaceful life of the Indonesian people, because Indonesia is a country that is prone to natural disasters, because geographically Indonesia is traversed by the Pacific Ring of Fire and the Alfide Belt. ${ }^{1}$ Conditions like this make Indonesia not immune from the threat of natural disasters. The handling of one disaster has not yet been completed, the next disaster will occur, be it floods, landslides, volcanic eruptions, tsunamis, liquefaction, or earthquakes.

BNPB stated that the disasters that occurred in 2018 increased from the previous year. During 2018 January to Thursday 25 October 2018, 1,999 natural disasters occurred in Indonesia, and this number will continue to grow until the end of 2018. The number of people who died and went missing in 2018 reached 3,584 people, meanwhile 13,112 people were injured, 3.06 million people were displaced and affected by the disaster, and 357,820 houses were damaged. ${ }^{2}$

Exactly on Friday, September 28, 2018 at 18:02 based on Indonesian middle time, there was a tectonic earthquake measuring 7.4 on the Richter Scale which was followed by a tsunami

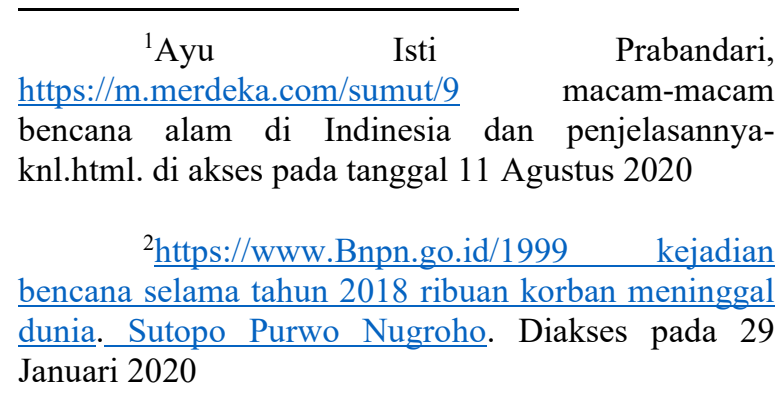

up to a height of 5 meters in Palu City. According to information announced by BNPB on October 21 that the death toll from the earthquake was recorded at 2,256 people, it was found that most was in Palu at 1,703 people and followed by Sigi, Parigi and Pasangkayu. Meanwhile, 1,309 people disappeared, 4,612 people were injured, and 223,751 people evacuated, in 122 places. ${ }^{3}$

Natural disasters, one of which is an earthquake, is an unexpected natural event that causes losses and damage. The impact of this natural disaster will cause grief and anxiety, not only for the Palu City community but also for all people in Indonesia.

Natural disasters have an impact on individuals and families, namely disruption of physical and mental problems due to traumatic events, other impacts, namely causing losses and suffering so that they affect aspects of life, both environmental and social. 4

Disasters that occur in addition to damage to infrastructures, the impact that is most felt is a traumatic event that causes deep and prolonged mental problems if not handled properly and immediately. At any event or incident that causes a feeling of being threatened physically or psychologically, whether the threat is real or only in the mind, it

${ }^{3}$ https://www.bnpn.go.id/ tsunami terjang pantai palu penanganan darurat terus dilakukan, Sutopo Purwo Nugroho. Diakses pada 29 Januari $\underline{2020 .}$.

${ }^{4}$ Keliat, B.A., Daulima, N.H.C., \& Farida, P. Manajemen Keperawatan Psikososial dan Kader Kesehatan Jiwa CMHN (Intermediate Course). (Jakarta: EGC, 2011) 156 
makes insecure and helpless and feels unable to bear it. ${ }^{5}$

The psychosocial aspect of disaster conditions is an approach to encourage the resilience of communities and individuals who are victims of disasters. Handling is very important and complicated, because it focuses more on the human psyche and social. Mental and social are part of the psychosocial aspects related to thoughts, emotions and human personality. In addition to the psychosocial aspect, the spiritual aspect also affects the impact of trauma due to disasters.

The disasters that occur in Indonesia are natural events that have a major impact on the Indonesian population. Victims of natural disasters in the form of individuals, families and community groups who suffer both physically, mentally and socioeconomically. As a result of the occurrence of disasters, it will cause obstacles in the implementation of human life. ${ }^{6}$

Disaster events can change a person's spiritual pattern, it can be positive or negative. The spiritual aspect is related to human identity, which connects with the Creator. These aspects can be used in dealing with problems in humans and their lives. These two aspects are invisible, cannot be touched,

${ }^{5}$ Achmanto Mendatu, Pemulihan Trauma: Strategi Penyembuhan Trauma Untuk Diri Sendiri, Anak, dan Orang Lain di Sekitar Anda (Yogyakarta: Panduan, 2010), 17.

${ }^{6}$ Murdiyanto dan Tri Gutomo, Bencana Banjir dan Tanah Longsor dan Upaya Masyarakat dalam Penaggulangannya. Jurnal PKS Vol 14 No 4 Desember 2015. 438 and are quite complicated to study and intervene.

Human is basically not the owner of an absolute soul, what they have, both body and life, essentially belongs to God. Allah has bestowed His favor on humans in the form of life, but its status is only a deposit as a form of trust. In carrying out human life, we are always in a test arena with various kinds of trials.

Meanwhile, "spiritual intelligence" is a person's ability to understand the meaning of worship for each of his behavior and be close to the creator. Indicators of Spiritual Intelligence include: feeling the presence of Allah swt. ${ }^{7}$

One of the functions of religion in human life that was put forward by Elizabeth K. Nottingham is as a savior in a condition of helplessness. Psychologically, the values of religious teachings can form inner turmoil by returning to the guidance of good and true religious teachings in accordance with religious law.. ${ }^{8}$

It can be concluded that humans who have more steadfast religious beliefs will more easily neutralize the shocks and conflicts that occur in their hearts. Belief and trust in Allah are made as a choice of shelter and Allah is considered the only helper or way to achieve salvation that can reduce the suffering they are experiencing. On the other hand, people with a low religious level, or even having no faith at all, will

\footnotetext{
${ }^{7}$ Toto Tasmara, Kecerdasan Ruhaniah (Transcenedental Intellegence), (Jakarta: Gema Insani, 2001), 14.

${ }^{8}$ Jalaludin, Psikologi Agama ...159

e-ISSN: 2715-4572

p-ISSN: 2716-1439
} 
find it difficult to neutralize the shock of their souls, find it difficult to find a way out of their problems, easily in despair and eventually take shortcuts.

Based on the author's initial observations at SMP Negeri 15 Palu, it was found that after the earthquake or in the early days of entering school there were some students who were indeed disturbed by their mental and psychological states, the first because there were some students whose uniforms and school equipment were lost and nothing was left when they were hit by the earthquake and tsunami at that time, so they felt ashamed and reluctant to go to school as if they were pessimistic about what had happened to them.

Then most of the students experienced trauma from what they had seen and felt during the incident, so that their behavior and thoughts did not feel calm and peaceful. After the school and parents cooperated in instilling religious values in students, little by little their trauma was eroded and they returned to being optimistic about returning to study and continuing their dreams. In fact, after the instillation of religious values has been carried out several times, students begin to realize that the disaster they have experienced comes from Allah, so they begin to obey in worship and be active in carrying out religious activities.

In fact, with strength and belief in the values of religious teachings will give a sense of inner peace. Returning to Allah by asking Him for protection is a channel that is in line with human instincts, because peace and safety are part of human instincts. In this case, it can be seen that religious belief will provide great opportunities for its adherents to get closer to Allah. With the remembrance of Allah the heart will become calm, can solve inner problems when you get a disaster.

\section{Literature review}

\subsection{Understanding Spirituality}

According to the Indonesian language, spiritual is "teaching which says that all reality is essentially spiritual". Spiritual intelligence is intelligence related to the ability to dhikr and pray before and after extracurricular activities. ${ }^{9}$ More specifically, "spiritual is the attitude of one's soul based on religious teachings so that it will give birth to a healthy mentality based on faith and devotion to Allah swt". ${ }^{10}$ It can be understood that, by having spiritual intelligence, students have the qualities of patience, tend to be kind, and always remember Allah swt, and are able to regulate emotions, discipline, work hard, and always respect others.

The word "spirit" comes from the Latin "spiritus" which means spirit, soul, self-awareness, disembodied being, breath of life, life. Which in its

${ }^{9}$ Toto Tasmara, Kecerdasan Ruhaniah (Transcenedental Intellegence), (Jakarta: Gema Insani, 2001), 17.

${ }^{10}$ Siti Binti, Pola Komunikasi Ustadzah Dalam Pembentukan Mental Spiritual Santriwati Pada Perguruan Diniyyah Putri Negeri Sakti Kabupaten Pesawaran Lampung (Bandar Lampung: LP2M IAIN Raden Intan Lampung, 2014), h. 52. 
development, the word spirit is interpreted more broadly. The philosophers, connotes spirit with the power that animates and energizes the cosmos, the consciousness associated with faculties, desires, and immaterial beings, the ideal form of reason (intellectuality, rationality, morality, holiness or divinity). Being spiritual means having more ties to things that are spiritual or psychological than to things that are physical or material. ${ }^{11}$

Spirituality is awakening or selfenlightenment in achieving the meaning of life and the purpose of life. "Spirituality is an essential part of a person's overall health and well-being." Thus it can be understood that spirituality is the most important center of one's health and well-being.

According to Jalaluddin Rahmat, spiritual intelligence is the ability of people to give meaning to life to stay happy in any situation regardless of the situation. The characteristics of spiritually intelligent people include being happy to do good, happy to help others, have found their purpose in life, so they feel carrying a noble mission and then feel connected to the source of power in the universe (God or whatever they believe in, the power of the universe for example), and have a good sense of humor. ${ }^{12}$

Based on the understanding above, it can be understood that, spiritual is

\footnotetext{
${ }^{11}$ Aliah B. Purakania Hasan, Psikologi Perkembangan Islami... 287

${ }^{12}$ Digital Players "Cerdas Spiritual", artikel diakses pada 15 November 2019 dari http://digitalprayers.com/cerdas-spiritual-bedadengan-sikap-religius/
}

something that is influenced by culture, religion, the development of experience, so that changes will arise in a person by increasing self-awareness. Then there will be life that is able to bring love and trust in Allah swt, so that the divine values in it will be manifested through experience and self-improvement, and one's view of life is more than sensory, increasing wisdom and strength to achieve closer relationships. with divinity and the universe and eliminate the illusion of wrong ideas that come from the five senses.

\subsection{Mental Spiritual Development}

The Big Indonesian Dictionary explains the mental understanding that, "mental is defined as something related to the mind and human character that is not energy". Thus mental in the form of everything related to non-physical aspects of humans such as thoughts and emotions.

In psychiatry and psychotherapy, the word mental is often used instead of the word personality (personality) which means mental is all the elements of the soul including thoughts, emotions, attitudes and feelings, disappointing or encouraging, pleasant and so on. ${ }^{13}$

Based on the information above, it can be understood that mental is a state that describes the atmosphere of thoughts, feelings and attitudes in a person that cannot be seen by the five

\footnotetext{
${ }^{13}$ Luftiainun, "Spiritual dan Mental” Artikel diakses pada 15 Desember 2019 dari, http://luftiainun.blogspot.com/2012/11/perbedaanspiritual-dan-mental.html?m=1
}

e-ISSN: $2715-4572$

p-ISSN: 2716-1439 
International Journal of Contemporary Islamic Education

Vol. 3 No. 2 Tahun 2021

100

senses, but can be seen in human attitudes and actions.

The word mental is taken from the Latin word mens or metis which means has the meaning of soul, life, soul, spirit, spirit. ${ }^{14}$ Thus, mental are things related to a person's psyche that can affect behavior. Every behavior, expression and movement of a person is a picture of his mental state.

The word mental according to language means something related to the soul, character, brain, mind, and human spirit. ${ }^{15}$ Mental alludes to the problem of mind, reason, memory, or processes associated with thought, reason, memory, and the word mental is often used instead of personality which means that mental is all the elements of the soul including thoughts, emotions, attitudes and feelings that in its whole and roundness will determine the style of behavior, how to deal with something that suppresses feelings, disappoints or delights, pleases and so on.

Meanwhile, H.M Arifin stated that the mental meaning is "something power that is abstract (not visible) and cannot be seen by the five senses about its form and substance, but what is visible is only the symptoms". Thus, mental intelligence is intelligence related to ability, focusing the mind and being able to maintain good morals. With

\footnotetext{
${ }^{14}$ Kartini Kartono, Jenny Andari, Hygiene Mental dan Kesehatan Mental dalam Islam (Bandung: Mandar Maju, 1989), 3.

${ }^{15}$ Zakiah Daradjat, Pendidikan Agama dan Pembinaan Mental (Jakarta: Bulan Bintang, 1968) 35.
}

mental intelligence, students are able to adjust to the environment, be polite, disciplined, respect others and so on.

\subsection{Factors Affecting Spirituality}

Some psychologists have talked a lot about the factors that influence the development of the religious spirit in adolescents. Abu Ahmadi and Munawar Sholeh, argued that the factors that influence development are heredity (inheritance) and environmental factors. ${ }^{16}$

\section{a. Heredity Factor}

Heredity has an important role in the growth and development of children. Where he was born into this world brought various kinds of inheritance that came from both mothers and fathers or grandmothers and grandfathers. The most important inheritance is body shape, facial expression, skin color, religion, intelligence, talent, character and disease. Inheritance brought by children from the womb mostly comes from their parents and the rest comes from their grandparents.

\section{b. Environmental factor}

The environment is considered as to the family that cares for and raises children, a school where to educate, a community where children hang out and play everyday and the surrounding natural conditions with their climate, flora and fauna. The size of the influence

\footnotetext{
${ }^{16}$ Abu Ahmadi, Munawar Sholeh, Psikologi Perkembangan, (Jakarta: Rineka Cipta, 2005), Cet. I, 47-56.

e-ISSN: 2715-4572

p-ISSN: 2716-1439
} 
International Journal of Contemporary Islamic Education

Vol. 3 No. 2 Tahun 2021

101

of the environment on growth and development depends on the state of the child's environment and his physical and spiritual.

Family is the most important primary group in society. The family is a group formed from the relationship of men and women, the relationship which more or less lasts a long time to create and raising children. ${ }^{17}$ In other words, the family is the smallest social unit consisting of husband and wife and if there are children, it is preceded by marriage. It can be understood that a family is two or more people who live together, whether it is related by blood or adoption and marriage created by a husband and wife who have children who live together and have the obligation to raise and educate their children.

Family is a multidimensional concept. It means, Family has many functions. The family, which brings a child into this world, is naturally in charge of educating the child. Since childhood, the child lives, grows and growing up in the family. The whole family was the first to fill the child's personality. Parents inadvertently instill habits inherited by their ancestors and other influences they receive from society. Parents are obliged to raise and educating children so that later the child's personality can be formed according to what parents expect.

${ }^{17}$ Abu Ahmadi, Psikologi Sosial, (Jakarta: Rineka Cipta, 2009), 221

\section{Methodology}

In conducting the study, we used a qualitative case study method. The case of this study was a state senior high school in Palu city. Data were gathered through direct field observation, indepth interviews which involve teachers and the school principle. We also analyzed written material ${ }^{18}$, such as the school teaching activities, to understand how the teachers inplement multicultutal based religious education.

We used a qualitative methods in this study wuth several considerations. First, the qualitative methods is helpful when dealing with multiple realities. Second, it can directly present the nature of the relationship between researchers and informants ${ }^{19}$. Third, this method is more sensitive and adaptable to the many sharpening of the common direction and the patterns of values encountered. ${ }^{20}$ While the data analysis is done using reduction and verification

${ }^{18}$.Nurdin, Nurdin, Stockdale, Rosemary, \& Scheepers, Helana. (2014b, 6-9 Jan. 2014). The Role of Social Actors in the Sustainability of EGovernment Implementation and Use: Experience from Indonesian Regencies. Paper presented at the System Sciences (HICSS), 2014 47th Hawaii International Conference on System Science.

${ }^{19}$.Nurdin, Nurdin, Stockdale, Rosemary, \& Scheepers, Helana. (2014a). Coordination and Cooperation in E-Government: An Indonesian Local E-Government Case The Electronic Journal of Information Systems in developing Countries, 61(3), 1-21.

${ }^{20}$ Nurdin, Nurdin. (2018). Institutional Arrangements in E-Government Implementation and Use: A Case Study From Indonesian Local Government. International Journal of Electronic Government Research (IJEGR), 14(2), 44-63. doi: 10.4018/ijegr.2018040104

e-ISSN: 2715-4572

p-ISSN: 2716-1439 
International Journal of Contemporary Islamic Education

Vol. 3 No. 2 Tahun 2021

102

techniques with various data sources. ${ }^{21}$ The reduced data is then analyzed by claiming to the theoretical concepts used in this study.

\section{Result and Discussion}

4.1 Student Spirituality Before and After the Earthquake.

The earthquake disaster compromises strong earthquakes, causing damage to housing, offices, schools, trees, and roads. In addition, the impact of the earthquake caused trauma and mental spirituality for the victims affected by the earthquake.

In an interview the author conducted with Mr. Abdul Rasyid as the principal, he said:

"SMP Negeri 15 Palu is somewhat different from other public schools in terms of character, both social attitudes and religious attitudes. When I first served as a principal at SMP Negeri 15 Palu, I was shocked by the behavior or character of the students, most of which are male". 22

In fact, from the beginning, the application and understanding of religion and religious values has been implemented at SMP Negeri 15 Palu. However, the condition of students who

21 Nurdin, Nurdin, \& Aratusa, Zana Chobita. (2020). Benchmarking level interactivity of Indonesia government university websites. TELKOMNIKA Telecommunication, Computing, Electronics and Control, 18(2), 853-859.

${ }^{22}$ Abdul Rasyid, Kepala Sekolah SMP Negeri 15 Palu, "wawancara" lewat Vedio Call, Pada tanggal 23 April 2020 pay less attention to religious values, thus making Islamic religious lessons in the junior high school slow. In an interview conducted by the author with Mrs. Herni Said as the deputy head of the school in the field of PR, said that: "in carrying out religious activities or deepening religious values, less than $75 \%$ of students who carry out the program". 23

One of the students of SMP Negeri 15 Palu said, "Before the earthquake I was the laziest to give alms, because I thought what to do with alms, I'd rather eat, which makes me full". Muhammad Raditya Parampasi also said that: "Before the earthquake I felt that prayer was just an ordinary routine without any meaning in carrying it out, sometimes it was even carried out sometimes not.". ${ }^{24}$ The same thing was said by Ahmad Dani as a student of SMP Negeri 15 Palu that: "I am the laziest to pray, when it's time for prayer I just go to the canteen or just play, even I invite friends not to pray and stay here to play or eat". ${ }^{25}$

Based on the information above, it can be understood that the mental and spiritual development of students before the earthquake can be said to be not

\footnotetext{
${ }^{23}$ Herni Said, Wakil Kepala Sekolah Bidang HUMAS SMP Negeri 15 Palu, "wawancara" lewat Zoom meeting, Pada tanggal 21 April 2020

${ }^{24}$ Muhammad Raditya Parampasi, Peserta Didik SMP Negeri 15 Palu Kelas IX, "wawancara" di rumah Pada tanggal 20 April 2020

${ }^{25}$ Ahmad Dani, Peserta Didik SMP Negeri 15 Palu Kelas IX, "wawancara" di rumah pada tanggal 14 Agustus 2020

e-ISSN: $2715-4572$

p-ISSN: 2716-1439
} 


\section{International Journal of Contemporary Islamic Education \\ Vol. 3 No. 2 Tahun 2021 \\ 103}

good because there are still many students who do not comply with school rules, especially religious activities that have been held at SMP Negeri 15 Palu. In fact, students still lack an understanding of religion and it can be seen in the implementation of worship in their daily school environment, they are only limited to following school rules and being afraid of the teachers. They understand that religious teachings are still limited to what is considered important, whether it is mandatory or sunnah.

No one wants disaster to happen. However, if a disaster strikes unavoidably, such as an earthquake, it certainly brings a sense of trauma to those who feel it. In addition, as religious people, disasters are actually a test of faith and patience as well as selfintrospection in getting closer to Allah swt, the owner of the universe.

The students of SMP Negeri 15 Palu understand what is happening in their environment about the earthquake disaster that occurred in Palu. This author quoted from the results of interviews with students named Nesya, Saying

"The previous earthquake that hit the city of Palu was a small apocalypse and a warning from Allah swt, that Allah created this universe, Allah sent down the disaster in this Palu city area, so that his people know that Allah is almighty and Allah reminds all his servants to worship him, through the Qur'an, prayer, reading the
Qur'an and attending islamic scientific assemblies". ${ }^{26}$

Another student also said that "after the earthquake I began to think about the virtues and benefits of prayer, so that I no longer be lazy to pray". Based on the results of the interviews above, it can be understood that, with the earthquake that hit the city of Palu, it made students who were initially lazy in doing worship at school, decreased because they felt that God had given them the opportunity to live and reprimand and warned that no longer commit religious transgressions and abandon His commandments. This was emphasized by Mrs. Herni Said as the deputy head of the school in the field of PR, that:

"In the implementation of religious activities or the deepening of religious values, the students were so enthusiastic about participating in religious activities, before the earthquake less than $75 \%$ of the students carried out the program, but after the earthquake, more than 90 percent of the students who participated in the religious activity program". 27

The students of SMP Negeri 15 Palu, the victims of the Palu city earthquake, are getting better and better with their relationship with the creator

\footnotetext{
${ }^{26}$ Nesya, Peserta Didik SMP Negeri 15 Palu Kelas IX, "wawancara" di rumah (ruang tamu) Pada tanggal 15 Juni 2020

${ }^{27}$ Herni Said, Wakil Kepala Sekolah Bidang HUMAS SMP Negeri 15 Palu, "wawancara" lewat Zoom meeting, Pada tanggal 21 April 2020
}

e-ISSN: 2715-4572

p-ISSN: 2716-1439 
by seeing these natural events. This is in accordance with the words of $\mathrm{Mr}$. Basirun as the deputy head of the school in the field of curriculum, that :

"In fact, with the earthquake that hit Palu City previously, the students of SMP Negeri 15 Palu were very enthusiastic in participating in religious activities organized by the school, they even wanted additional studies before dhuhur and dhuha prayers in congregation.". 28

The head of SMP Negeri 15 Palu Abdul Rasyid added that: "Students of SMP Negeri 15 Palu after the earthquake changed in terms of character and there were several things that were known, namely the spiritual state, the religious condition of students was more improved". 29

Then Mrs. Agus Ratna's as an Islamic Religious Education teacher added:

"students of SMP Negeri 15 Palu, after the previous earthquake that hit Palu City, their mental and spirituality has greatly improved, and it can be seen by their enthusiasm for participating in religious activities, such as dhuha in congregation, dhuhur in congregation, yasinan together and bimtaq activities. If before the

\footnotetext{
${ }^{28}$ Basirun, Wakil Kepala Sekolah Bidang Kurikulum SMP Negeri 15 Palu, "wawancara" lewat Zoom meeting, Pada tanggal 21 April 2020
}

${ }^{29}$ Abdul Rasyid, Kepala Sekolah SMP Negeri 15 Palu, "wawancara" lewat Vedio Call, pada tanggal 23 April 2020 disaster, the students during the dhuhur and dhuha time together will be sought and chased by the teacher, after the earthquake they are no longer sought and chased, but instead they invite and ask the teacher if it is time for dhuha and dhuhur together". ${ }^{30}$

\subsection{Teacher's Role in Developing Spirituality}

The role of the teacher in developing the spiritual mentality of students greatly affects the quality of life that students live in their daily lives, so that Islamic religious education teachers and teachers of other subjects are required to be able to carry out their duties, namely fostering and shaping spiritual mentality according to their level and understanding. they are both in the learning process and in interacting with people around them, this is intended so that participants can behave properly and correctly according to the teachings of Islam.

Based on the results of interviews with the principal, Abdul Rasyid regarding the role of teachers in developing mental, spiritual and emotional intelligence he said: "I invite all teachers to work together in giving touch to students, the touch is done every morning at Duha prayer and imtaq activities every morning. week in

${ }^{30}$ Agusratna, Guru Pendidikan Agama Islam SMP Negeri 15 Palu, "wawancara" di sekolah Pada tanggal 20 April 2020

e-ISSN: $2715-4572$

p-ISSN: 2716-1439 
International Journal of Contemporary Islamic Education

Vol. 3 No. 2 Tahun 2021

105

instilling character and moral attitudes". 31

Mrs. Herni Said as the deputy head of the school for public relations also said that:

"teachers and students make movements and expressions to be more enthusiastic and provide direction to students that natural disasters are not our will, but God's will. The school also cooperates with UNICEF and SMP Madani in reducing the trauma felt by students". 32

Mr. Basirun as the deputy head of the school in the field of curriculum also added that: "teachers always invite students to pray before starting school activities that are carried out in the field because they still feel anxious if it was done inside a room. ${ }^{33}$

As for the efforts made by Islamic religious education teachers and general teachers in developing the mental spirituality of post-disaster students in State Junior High Schools, among others, the habit of practicing religious teachings is the main parameter of this life. Religious education, school education should emphasize the habit of worshiping by the students, namely

\footnotetext{
${ }^{31}$ Abdul Rasyid, Kepala Sekolah SMP Negeri 15 Palu, "wawancara" lewat Vedio Call, pada tanggal 23 April 2020

${ }^{32}$ Herni Said, Wakil Kepala Sekolah Bidang HUMAS SMP Negeri 15 Palu, "wawancara" lewat Zoom meeting, pada tanggal 21 April 2020

${ }^{33}$ Basirun, Wakil Kepala Sekolah Bidang Kurikulum SMP Negeri 15 Palu, "wawancara” lewat Zoom meeting, Pada tanggal 21 April 2020
}

habits to carry out or practice religious teachings, for example getting used to praying in congregation at the mosque at the beginning of time, reading the Qur'an, dhikr, and so on.

The habit of doing this worship is carried out in order to always improve and develop the mental spirituality of students at SMP Negeri 15 Palu, this is in accordance with the expression of the headmaster of SMP Negeri 15 Palu, Abdul Rasyid, said:

"As a teacher who guides and educates students at SMP Negeri 15 Palu, he must familiarize students with carrying out worship such as praying Duhur in congregation, praying Duha in congregation and praying Friday prayers at the mosque, reading the Qur'an before entering class and studying, paying homage when one of the residents of SMP Negeri 15 Palu experienced a disaster, memorized the prayer readings, and fostered the morals of students in speaking and behaving well towards their friends and teachers". 34

This opinion is also supported by the statement of Mr. Herman, a teacher of Islamic Religious Education at SMP Negeri 15 Palu as follows :

"At the beginning of the lesson I teach, as a teacher I always asked students questions about past lessons, that's where I found out

\footnotetext{
${ }^{34}$ Abdul Rasyid, Kepala Sekolah SMP Negeri 15 Palu, "wawancara" lewat Vedio Call, pada tanggal 23 April 2020
} 


\section{International Journal of Contemporary Islamic Education}

Vol. 3 No. 2 Tahun 2021

106

whether they still remembered or not memorized the prayer readings that I gave to those I taught yesterday, after that I tried again to the students to become an imam in the mosque so that the practice of reading prayer readings can be realized outside of school" 35

Based on the results of interviews and explanations regarding coaching or training in developing mental spirituality in students at SMP Negeri 15 Palu, it can be understood that by carrying out routine religious training and habituation, students will get used to doing these activities both at school and in the community, so that students are accustomed to carrying out good deeds, and here the role of the teacher in developing the spiritual mentality of students can be known by educating students to be polite in speaking, honest in speaking and not saying dirty words. The spiritual education given above is an effort to guide and train the behavior of students so that they always reflect the values of religious teachings so that they have good behavior in everyday life.

Based on observations, it is known that this habituation activity is carried out before learning begins, the 99 names of Allah are read by students together every day so that without memorizing students can remember all the contents of Asmaul Husna. All of that is part of introducing students to the attributes of the Creator from an

${ }^{35}$ Herman, Guru Pendidikan Agama Islam SMP Negeri 15 Palu, "wawancara" di sekolah pada tanggal 20 April 2020 early age. Students will grow straight when since childhood they have known the attributes of Allah and their monotheism will be firmly planted and their belief in God's help will be stored well in the hearts of students. The seeds of good morals will grow if the heart that seems like a field where the plants are blooming is always watered every day.

The implementation of the Duha prayer is a general activity and must be followed by all students of SMP Negeri 15 Palu. Based on the author's observations, this dhuha prayer activity is carried out every day except on Mondays and Fridays. Because on Monday there is a flag ceremony and on Friday there are workshops for the heart and joint sports. So the dhuha prayer activities are carried out four days a week.

The habit of praying dhuha in congregation aims to introduce the implementation of prayer and instill a love for students to maintain prayer. The habit of dhuha prayer has been implemented at SMP Negeri 15 Palu in accordance with one of the results of the teacher council meeting with the principal who unanimously decided that the program for habituation of dhuha prayer in congregation was deemed necessary to be carried out as a strategic step to foster the spiritual morals of students.

For students who do not take part in the dhuha prayer due to being late or intentionally not participating, they get sanctions and motivation as reinforcement from supervisors and e-ISSN: 2715-4572 p-ISSN: 2716-1439 


\section{International Journal of Contemporary Islamic Education}

Vol. 3 No. 2 Tahun 2021

107

other educators. Remembering that the dhuha prayer activity has good spiritual education value for the development of students.

\section{Conclusion}

The teacher has been able to carry out mental and spiritual recovery of the students after the natural disaster in Palu. The students who were initially lazy to participate in religious activities became diligent. Then the students who initially rarely prayed became diligent to pray. The teachers awaken students' awareness of the importance of maintaining spirituality after experiencing a disaster through various religious activities in the school environment.

\section{REFERENCES}

Ahmadi, Abu dan Akhmad Rohani, Bimbingan dan Konseling di Sekolah Jakarta: Rineka Cipta, 1991

$$
\text { \& Munawar Sholeh, }
$$

Psikologi Perkembangan, Jakarta:

Rineka Cipta, 2005, Cet. I,

Ahnan, Maftuh dan Zacky Syafa, Filsafat Manusia. Surabaya: Terbit Terang, 2001.

al-Falih, Abdullah Ibnu Sa'd, Langkah Praktik Mendidik Anak sesuai Tahapan Usia Bandung:Irsyad Baitus Salam, Jakarta: UIN Jakarta, 2006, Cet.Ke-1,

al-hafidz, Ahsin W. Fikih Kesehatan. Jakarta: AMZAH. 2010

al-Adawy, Syaikh Mustafa, Fikih Pendidikan Anak, Membentuk Kesalehan Anak sejak Dini,
Dilengkapi dengan Nasehat Para Dokter dan Psikologi Anak. Jakarta: Qisthi Perss, 2009

Amin, Samsul Munir, Bimbingan Dan Konseling Islam, Jakarta: AMZAH, 2010, Arief, Armai Reformasi Pendidikan Islam Ciputat: CRSD PRESS, 2007

Arifin, Imron, Penelitian Kualitatif dalam Ilmu-ilmu Sosial dan Keagamaan Malang: Kalimasada Press, 2010,

Arifin, M, psikologi dan Beberapa Aspek Kehidupan Rohaniyah Manusia, Jakarta: Bulan Bintang, 1976,

Bagus, Loren, Kamus Filsafat. Jakarta: PT. Gramedia Pusaka Utama. 2002

Baharuddin, Pendidikan dan Psikologi Perkembangan. Jogjakarta: ar-Ruzz Media. 2014.

Bungin, Burhan, Peneiltan Kualitatif, Komunikasi, Ekonomi, Kebijakan Publik, dan Ilmu Sosial lainnya, Edisi. I. Cet. I; Jakarta: Kencana Prenada Media Group, 2007,

Binti, Siti, Pola Komunikasi Ustadzah Dalam Pembentukan Mental Spiritual Santriwati Pada Perguruan Diniyyah Putri Negeri Sakti Kabupaten Pesawaran Lampung Bandar Lampung: LP2M IAIN Raden Intan Lampung, 2014

Daradjat, Zakiah, Ilmu Jiwa Agama, Jakarta: PT Bulan Bintang, 2009, Membina Nilai-nilai Moral di Indonesia. Jakarta: Bulan Bintang, 1971.

Dari Ensiklopedia Bebas, Dampak Bencana Alam, artikel diakses pada 15 November 2019, dari http://id.wikipedia.org/wiki/bencana_al $\underline{\mathrm{am}}$

Daulima, Keliat, B.A., N.H.C., \& Farida, P. Manajemen Keperawatan Psikososial dan Kader Kesehatan Jiwa CMHN

e-ISSN: 2715-4572

p-ISSN: 2716-1439 
International Journal of Contemporary Islamic Education

Vol. 3 No. 2 Tahun 2021

108

(Intermediate Course). Jakarta: EGC, 2011

Departemen Agama RI, Al-Qur'an dan Terjemahannya Bandung: Syamil Cipta Media, 2005

Desmita, Psikologi Perkembangan Peserta Didik, Bandung: PT Remaja Rosdakarya, 2010,

Digital Players "Cerdas Spiritual", artikel diakses pada 15 November 2019 dari http://digitalprayers.com/cerdasspiritual-beda-dengan-sikap-religius/

Dispenarmabar, "Pengertian Pembinaan Mental (Bintal)" dalam http:// koarmabar. tnial. mi.id /aRTIKEL /BINTAL /tabid /26/.aspx diakses pada tanggal 12 Juli 2020

Endarto, D. \& K. Rahman, Mengetahui Seluk-beluk Gempa Bumi. Sukaharjo: CV. Graha Printama Selaras. 2019

Hasan, Aliah B. Purwakania Psikologi Perkembangan Islami: Menyingkap Rentang Kehidupan Manusia dari Prakelahiran Hingga Pasca Kematian, edisi 1 Jakarta: PT Rajagrafindo Persada, 2006.

Hastati, Netty dkk., Islam dan Psikologi Jakarta: PT. Raja Grafindo Persada, 2005,

Hurlock, Elizabet B. Perkembangan Anak Edisi Ke-6, Jilid 1 Jakarta: Erlangga, 1978 ,

$$
\text { Psikologi }
$$

Perkembangan. Jakarta : Erlangga, 2003.

$$
\text { Developmental }
$$

Psychology, Terj. Istiwidayanti dan Soedjarwo, Psikologi Perkembangan Sepanjang Rentang Kehidupan, Jakarta: Erlangga, 1980.

Idi, Abdullah \& Safarina Hd, Etika Pendidikan Keluarga Sekolah dan Masyarakat. Jakarta: PT. RajaGrafindo Persada, 2016.
Ihsan, Fuad, Dasar-dasar Kependidikan Jakarta: Renika Cipta, 1996 Cet.Ke-1, Iskandar, Metodologi Penelitian Pendidikan dan Sosial Jakarta: Ikapi, 2013, Jalaluddin, Psikologi Agama Jakarta: RajaGrafindoPersada, 2016.

Jahja, Yudrik, Psikologi Perkembangan.

Jakarta: Kencana. 2011)

Kartono, Kartini, Psikologi Anak (Psikilogi Perkembangan). Cet.Ke-IV Bandung: Mandar Maju, 1990.

Khaeruman, Badri, Moralitas Islam

Bandung: Pustaka Setia, 2003.

Luftiainun, "Spiritual dan Mental" Artikel diakses pada 15 Desember 2019 dari, http://luftiainun.blogspot.com/2012/11/ perbedaan spiritual dan mental.

Mahmud, Metode Penelitian Pendidikan

Bandung: Pustaka Setia, 2011,

Mahcmud, Tedy, Rasionalisme dan Emperisme. Jurnal Ivovasi, Vol 8, No 1, Maret 2011

Margono, S. Metode Penelitian Pendidikan,

Cet. II; Jakarta: Rineka Cipta, 2000,

Mendatu, Achmanto, Pemulihan Trauma: Strategi Penyembuhan Trauma Untuk Diri Sendiri, Anak, dan Orang Lain di Sekitar Anda Yogyakarta: Panduan, 2010 ,

Milles, Matthew B. dan A. Michael Huberman, Qualitative Data Analisis, diterjemahkan oleh Tjecep Rohendi Rohili dengan judul Analisis Data Kualitatif: Buku tentang Metodemetode Baru, Cet. I; Jakarta: UI Pres, 2005,

Moeliono, Anton M. kamus Besar Bahasa Indonesia Jakarta: Blai Pustaka, 1989

Moersintowari BN, Pertumbuhan dan Perkembangan Anak dan Remaja Surabaya: Continuing Education Ilmu Kesehatan Anak FK. UNAIR, 2005. 
International Journal of Contemporary Islamic Education

Vol. 3 No. 2 Tahun 2021

109

Moleong, Lexy J. Metodologi Penelitian Kualitatif Cet. XVII; Bandung: PT. Remaja Rosdakarya, 2002,

Muhyani, Pengaruh Pengasuhan Orang Tua dan Peran Guru di Sekolah Menurut Pesepsi dan Kesehatan Mental Jakarta Pusat: Kementrian Agama Republik Indonesia, 2012

Mufadhdhal, Abiy al-Qasim al-Husain ibn Muhammad ibn \& Al-Ma'ruf bi alRhaghib al-Ashfajiy, Mufradat Alfaz al-Qur'an Damaskus: Dar al-Qalam, 2002

Mujib, Abdul dan Jusuf Mudzakir, NuansaNuansa Psikologi Islam, Jakarta: PT Raja Grafindo Persada, 2001,

Munadir, Ensiklopedia Pendidikan Malang: UM Press, 2001,

Mussen, Paul Henry dkk., Perkembangan dan Kepribadian Anak Ed Ke-6 Jakara: Erlangga, 1984.

Nata, Abuddin, Metodologi Studi Islam Cet.Ke-6 Jakarta: Raja Grafindo Persada, 2001,

Notosoedirojo, Moeljono dan Latipun, Kesehatan Mental Malang: UMM Press, 2016,

Nugroho, Sutopo Purwo, https://www.bnpn.go.id/ 1999 kejadian bencana selama tahun 2018 ribuan korban meninggal dunia. Diakses pada 29 Januari 2020

Nugroho, Sutopo Purwo, https://www.bnpn.go.id/ tsunami terjang pantai palu penanganan darurat terus dilakukan. Diakses pada 29 Januari 2020.

Nurdin, Nurdin, Stockdale, Rosemary, \& Scheepers, Helana. (2014a). Coordination and Cooperation in E-Government: An Indonesian Local E-Government Case The Electronic Journal of Information
Systems in developing Countries, 61(3), 1-21.

Nurdin, Nurdin. (2018). Institutional Arrangements in E-Government Implementation and Use: A Case Study From Indonesian Local Government. International Journal of Electronic Government Research (IJEGR), 14(2), 44-63. doi: 10.4018/ijegr.2018040104

Nurdin, Nurdin, Stockdale, Rosemary, \& Scheepers, Helana. (2014b, 6-9 Jan. 2014). The Role of Social Actors in the Sustainability of E-Government Implementation and Use: Experience from Indonesian Regencies. Paper presented at the System Sciences (HICSS), 2014 47th Hawaii International Conference on System Science.

Nurdin, Nurdin, \& Aratusa, Zana Chobita. (2020). Benchmarking level interactivity of Indonesia government university websites. TELKOMNIKA Telecommunication, Computing, Electronics and Control, 18(2), 853-859.

Nurjanah., dkk Manajemen Bencana. Bandung: Alfa Beta, 2012.

Purwanto, M. Ngalim, Psikologi Pendidikan, Cet. XX; Bandung: PT. Remaja Rosdakarya, 2004

Puspita, Ratna, Kontribusi Emperisme Terhadap Pendidikan Ilmu Pengetahuan Sosial. Jurnal Edueksos Vol 1 No 1, Januari-Juni 2012

Puteh, Yusri, https:// www.ajnn.net/ news/ bencana cara Allah menguji orang beriman/ amp. html. Diakses pada tanggal 17 Juli 2020

Raharjo, Pengantar Ilmu Jiwa Agama. Pustaka Rizki Putra: Semarang, 2012.

e-ISSN: 2715-4572

p-ISSN: 2716-1439 


\section{International Journal of Contemporary Islamic Education}

\section{Vol. 3 No. 2 Tahun 2021}

110

Ramayulis, Pengantar Psikologi Agama, Jakarta: Kalam Mulia, 2002, Cet. VI.

Ruslan, Rosady, Metode Penelitian Public Relation dan Komunikasi, Cet. IV; Jakarta: PT. Raja Grafindo Persada, 2004,

Santrock, Jhon W. Adolescence Perkembangan Remaja, Jakarta: Erlangga,2002, , perkembangan Anak Edisi 11, Jilid 2, Jakarta: Erlangga, 2007.

Sarlito W, Sarwono , Psikologi Remaja, Jakarta: PT Raja Grafindo Persada,2004,

Sit, Masganti, Perkembangan Peserta Didik. Medan: PERDANA PUBLISHING, 2012 ,

Soetjiningsih, Tumbuh Kembang Anak dan Remaja, pada Pendidikan Ilmu Kesehatan Anak Denpasar: FK UNUD, 2007

, Tumbuh Kembang Remaja dan Permasalahannya. Jakarta: CV Sagung Seto, 2004.

Sobur, Alex, Psikologi Umum Bandung: Pustaka Setia, 2003,

Sugiono, Metode Penelitian Pendidikan; Pendekatan Kuatitatif, Kualitatif, dan $R \& D$, Cet. 21; Bandung: Alfabeta, 2015

Solihin, M. Terapi Sufistik Penyembuhan Penyakit Kejiwaan Perspektif Tasawuf Bandung: Pustaka Setia, 2004

Sukardi, D. Ketut, Dasar Bimbingan Penyuluhan di Sekolah Surabaya; Usaha Nasional, 1991

Sururin, Ilmu Jiwa Agama Jakarta: PT RajaGrafindo Persada, 2004,

Suryabrata, Sumadi, Psikologi Pendidikan Jakarta: PT. Raja Grafindo Persada, 1993

Syah, Muhibbin, Psikologi Pendidikan Suatu Pendekatan Baru. Bandung: Remaja Rosdakarya, 1995
Syarifah,

https://republika.co.id/berita/msc3n1/m emaknai-musibah. Diakses pada tanggal 17 Juli 2020

Tadjab, Ilmu Jiwa Pendidikan, Cet. I; Surabaya: Karya Abditama, 1994

Tafsir, Ahmad, Ilmu Pendidikan dalam Perspektif Islam (Bandung: Remaja Rosdakarya, 2001)

Tasmara, Toto, Etos Keja Pribadi Muslim Yokyakarta: Dana Bakti Primayasa, 2003,

(Transcenedental Intellegence), Jakarta: Gema Insani, 2001,

Tim Penyusun Kamus Pusat Pembinaan dan Pengembangan Bahasa, Kamus Besar Bahasa Indonesia, Cet, Ke-1 Edisi Tiga Jakarta: Balai Pustaka, 1998,

Tim Penyususn Kamus Pusat Pembinaan dan Pengembangan Bahasa, Departemen Pendidikan dan Kebudayaan, Kamus Besar Bahasa Indonesia Cet.Ke-III, Jilid, I, Jakarta: Balai Pustaka, 1990

Tohirin, Psikologi Pembelajaran Pendidikan Agama Islam (Berbasis Integrasi dan Kompetensi). Jakarta: PT RajaGrafindo Perada, 2008,

Uhbiyati, Nur, Ilmu Pendidikan Islam 2 Bandung: CV. Pustaka Setia, 1997,

Umar, Husein, Metode Penelitian untuk Skripsi dan Tasir Bisnis, Cet. IV; Jakarta: PT. Raja Grafindo, 2010,

Undang-undang Nomor. 24 tahun 2007, tentang Penanggulangan Bencana, Bab I, Pasal.1 artikel diakses pada 15 November 2019 dari www.bnpn.go.id/website/file/publikasi 141.pdf

Willis. Sofyan S. Remaja dan Masalahnya. Mengupas Berbagai bentuk Kenakalan Remaja seperti Narkoba, Freesex dan Pemecahannya. Bandung: CV Alfabeta, 2005. 
International Journal of Contemporary Islamic Education

Vol. 3 No. 2 Tahun 2021

111

Winarno Surakhmad, Dasar dan Teknik Research. Pengentar Metodologi Ilmiah Bandung: Torsito, 2000,

Yusuf, Syamsu, Psikologi Perkembangan Anak dan Remaja. Bandung: PT Remaja Rosdakarya, 2011.

Zahrotun, dkk, Psikologi Perkembangan

Tinjauan Psokologi Barat dan Psikologi Islam 